\title{
Macro- and microscopic leaf injury triggered by ozone stress in beech foliage (Fagus sylvatica L.)
}

\author{
Pierre Vollenweider $^{1} \cdot$ Madeleine S. Günthardt-Goerg $^{1}$ (D) $\cdot$ Terry Menard $^{1} \cdot$ Manuela Baumgarten $^{2} \cdot$ Rainer Matyssek $^{2} \cdot$ \\ Marcus Schaub ${ }^{1}$
}

Received: 6 November 2018 / Accepted: 24 June 2019 / Published online: 9 July 2019

(C) INRA and Springer-Verlag France SAS, part of Springer Nature 2019

\begin{abstract}
- Key message The diversity of structural injury underlying visible symptoms by ozone stress resulted from the succession of degenerative processes and programmed-cell death events, depending on the ozone uptake and varying on a year-toyear basis.

- Context The effects of tropospheric ozone $\left(\mathrm{O}_{3}\right)$ on the vegetation will remain a lasting concern during the twenty-first century, and deeper understanding of functional and structural responses to $\mathrm{O}_{3}$ in plant foliage in a changing environment is needed.

- Aims Comprehensive analysis of the $\mathrm{O}_{3}$ injury spectrum, with a view to functional understanding of cellular processes in response to varying $\mathrm{O}_{3}$ doses.

- Methods Characterization of macro- and microscopic symptoms in the sun crown foliage of adult trees exposed to ambient and twice ambient $\mathrm{O}_{3}$ levels in a Free Air $\mathrm{O}_{3}$ Enrichment (FACE) experiment using light and electron microscopy.

- Results Visible injury triggered by $\mathrm{O}_{3}$ resulted from (i) degenerative processes of varying severity (photobleaching, accelerated cell senescence, ACS), (ii) programmed cell death with disruption of cell content (hypersensitive reaction-like, HR-like) and occasional leakage of cellular debris into the apoplast, (iii) overlapping degenerative and disruptive processes, primarily in the upper mesophyll and within organelles prone to oxidative stress (chloroplasts and mitochondria) and (iv) necrosis in lower mesophyll with leakage of cellular debris in the intracellular space.

- Conclusion Especially the degenerative and disruptive traits showed contrasting structural features. In the case of stippling symptoms, the structural variability was particularly high, as a consequence of interactions between early degenerative and late disruptive processes. These findings thus confirmed the close dependency of processes - and a further spectrum of ozone injury — on rates of ozone uptake. Such relationships and development of injury, as observed in the case of beech (Fagus sylvatica L.) foliage, are expected to be basically similar in other broadleaved tree species.
\end{abstract}

Keywords Ozone injury $\cdot$ Cell degeneration $\cdot$ Cell content disruption $\cdot$ Chloroplast degeneration $\cdot$ HR-like response $\cdot$ Accelerated cell senescence $\cdot$ Microscopic validation

\section{Introduction}

Implementing reliable air pollution abatements is an ongoing challenge (Watson et al. 2016). The background

Handling Editor: Michael Tausz

Madeleine S. Günthardt-Goerg

madeleine.goerg@wsl.ch

1 Forest Dynamics, Swiss Federal Research Institute WSL, Zürcherstrasse 111, 8903 Birmensdorf, Switzerland

2 Ecophysiology of Plants, TU München, Am Hochanger 13, 85354 Freising, Germany concentrations of ground-level ozone $\left(\mathrm{O}_{3}\right)$ have been steadily increased, even though peak levels have declined in intensity and frequency (Simon et al. 2015), as a consequence of recently appeared $\mathrm{O}_{3}$ "hot spots" and longdistance transport (Bytnerowicz et al. 2013). Because of multi-factorial interactions among the vegetation, atmosphere and $\mathrm{O}_{3}$ precursors, oxidative stress varies in severity from year to year and critical levels are commonly exceeded in various regions throughout the world (Cristofori et al. 2015; Moura et al. 2014a; Sá et al. 2016; Sharma et al. 2016). The prognoses beyond 2040 (Fuhrer et al. 2016; Klingberg et al. 2014) remain uncertain, as a reduction of $\mathrm{NO}_{x}$ and other emissions may not 
sufficiently alleviate the current $\mathrm{O}_{3}$ levels, as a consequence of climate warming (Garthwaite et al. 2009; Lauwaet et al. 2014). The $\mathrm{O}_{3}$ effects are mediated by stomatal influx, which is determined by $\mathrm{O}_{3}$ exposure but also by several other environmental drivers, especially soil water availability and vapour-pressure deficit (Baumgarten et al. 2009). During the exceptionally dry summer of 2003, the $\mathrm{O}_{3}$ uptake-despite higher exposure-was reduced, due to drought-induced closure of stomatal pores (Löw et al. 2006). Given stress response plasticity (Matyssek et al. 2012) and regional environmental peculiarities (Trenberth et al. 2014), ecosystem responses to $\mathrm{O}_{3}$ can be highly variable. Hence, the impact of ground-level $\mathrm{O}_{3}$ on vegetation will remain a lasting concern during the twenty-first century (Mills et al. 2016).

Visible symptoms in foliage, which provide some of the most obvious indications of $\mathrm{O}_{3}$ stress, are better reliable when verified by a combination of approaches including experimental exposure (Dai et al. 2017; Harmens et al. 2017; Novak et al. 2003; Paoletti et al. 2017) and microscopic validation (Alves et al. 2016; Simon et al. 2015; Vollenweider et al. 2013; Moura et al. 2018). These approaches have been used extensively for $\mathrm{O}_{3}$ monitoring and bioindication (Ferretti et al. 2015; Sanz and Calatayud 2011; Schaub et al. 2016). Beech (Fagus sylvatica L.) is a widespread tree species in Central Europe. Visible $\mathrm{O}_{3}$ symptoms usually reported for beech include gradients of interveinal bronzing, dark stippling and less specific leaf discoloration, increasing in severity along yearly shoot increments basipetally. However, the inter- and intraspecific variability of visible injury is astounding and complicates the diagnosis of $\mathrm{O}_{3}$ stress (Sanz and Calatayud 2011; Vollenweider and Günthardt-Goerg 2006).

Microscopic validation can ascertain an $\mathrm{O}_{3}$ injury diagnosis by providing mechanistic understanding of the cause and development of symptoms (Faoro and Iriti 2009; Günthardt-Goerg and Vollenweider 2007; Kivimäenpää et al. 2005). Previous research has demonstrated the close correlation between macro- and micromorphological symptoms (Moura et al. 2011, 2018; ReigArmiñana et al. 2004; Vollenweider et al. 2013) and has linked the variability of structural injury with that of processes and plant responses triggered or amplified by $\mathrm{O}_{3}$ stress in foliage (Faoro and Iriti 2009; Foyer and Shigeoka 2011; Calderón Guerrero et al. 2013; GünthardtGoerg et al. 1997; Günthardt-Goerg and Vollenweider 2007; Mikkelsen and Heide-Jørgensen 1996; Moura et al. 2014b; Pasqualini et al. 2003). Microscopic injury by $\mathrm{O}_{3}$ stress shows similar traits, irrespective of the taxonomic group (Bussotti et al. 2005; Günthardt-Goerg et al. 2000), and leaf sclerophylly (Calderón Guerrero et al. 2013; Reig-Armiñana et al.
2004). Further, structural markers indicative of other stress factors can show how $\mathrm{O}_{3}$ interacts with several environmental factors such as drought (Calderón Guerrero et al. 2013), light (Paoletti et al. 2010) or coldness during winter (Vollenweider et al. 2013). Microscopic validation is thus particularly insightful for understanding plant responses to $\mathrm{O}_{3}$ in a changing climate. However, such demanding evidence is still limited. Also missing is ultrastructural evidence of responses in different subcellular compartments and cell types, especially in the case of disruptive processes. Furthermore, in most reports (Table 1), only a few markers of $\mathrm{O}_{3}$ injury are described and there is a lack of comprehensive functional understanding regarding the effects of $\mathrm{O}_{3}$ stress at the cell level and for the different plant responses.

Given the availability of $\mathrm{O}_{3}$-exposed foliage in the CASIROZ experiment performed in a mixed forest on adult beech trees (Southern Germany, Matyssek et al. 2007), the objectives in the present study included to (i) characterize the spectrum of $\mathrm{O}_{3}$ injury within beech foliage by comprehensively analysing symptoms in the leaf blade at the tissue, cell and subcellular levels, (ii) relate the ozone stress markers mechanistically to physiological processes and responses and (iii) analyse the incidence of varying ozone dose on the spectrum of $\mathrm{O}_{3}$ injury and prevalence of physiological responses causing the observed $\mathrm{O}_{3}$ symptoms. Therefore, leaf samples were harvested repeatedly in the sun crowns of trees during field campaigns between 2000 and 2006, focusing on the different types of visible $\mathrm{O}_{3}$-like symptoms. The underlying structural injuries were extensively analysed, combining different methods in bright field light, fluorescence and transmitted electron microscopy (TEM).

\section{Material and methods}

\subsection{The experimental site}

This study made use of the Free Air $\mathrm{O}_{3}$ Enrichment (FACE) facility within the framework of the CASIROZ experiment (Carbon Sink Strength of Fagus sylvatica L. in a Changing Environment-Experimental Risk Assessment of Mitigation by Chronic Ozone Impact). In a mixed stand within Kranzberg Forest, $35 \mathrm{~km}$ northeast of Munich, Germany ( $48^{\circ} 25^{\prime} \mathrm{N}, 11^{\circ} 39^{\prime} \mathrm{E}, 485 \mathrm{~m}$ asl), two neighbouring groups of five beech trees each (Fagus sylvatica L.), about 60 years old and $27 \mathrm{~m}$ high, were exposed to either the unchanged ambient or experimentally enhanced twice-ambient $\mathrm{O}_{3}$ regime (both naturally fluctuating) from April through October each during the period of 2000 to 2007. The experimental design has been detailed in several papers (Karnosky et al. 2007; 


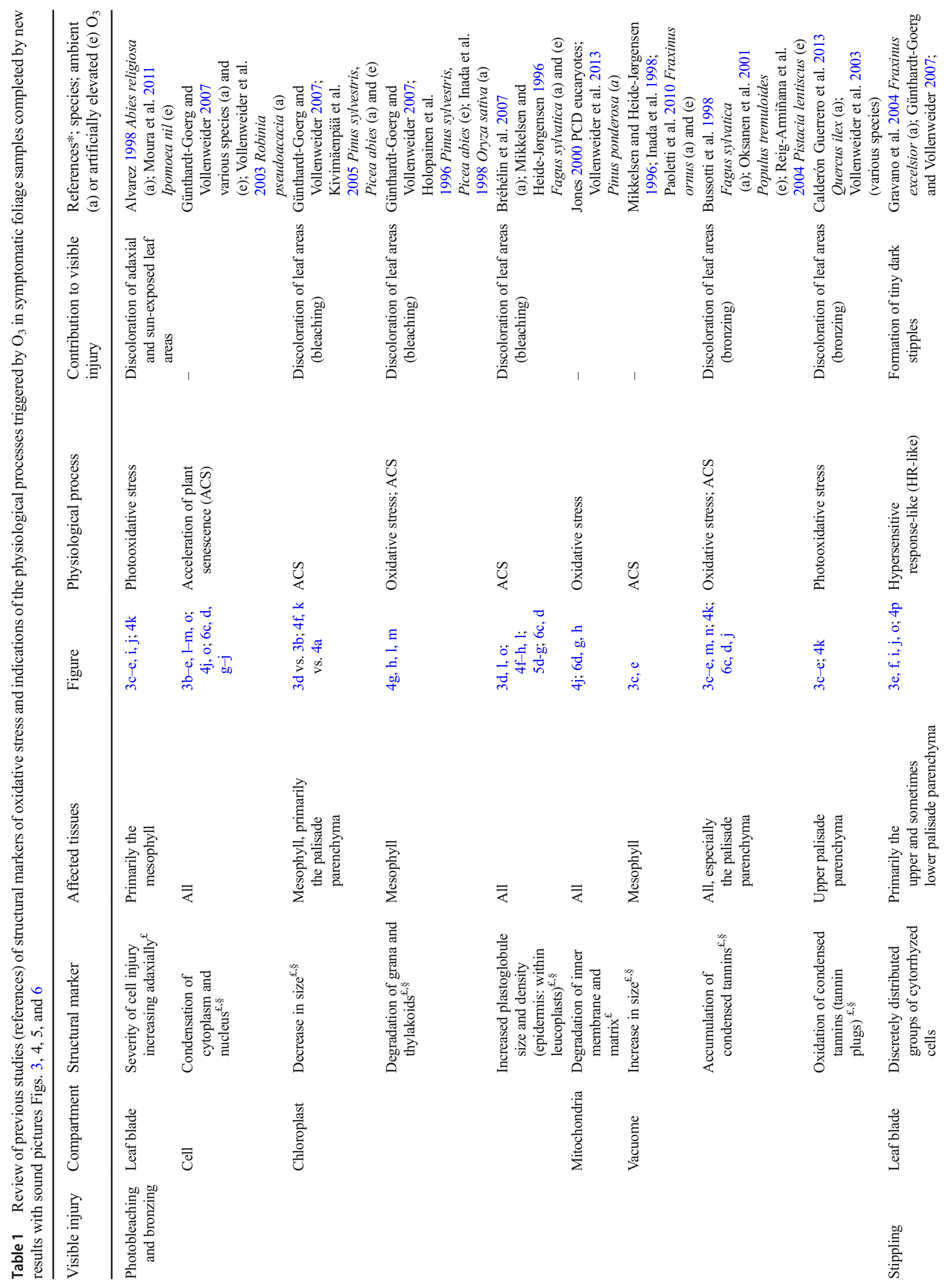




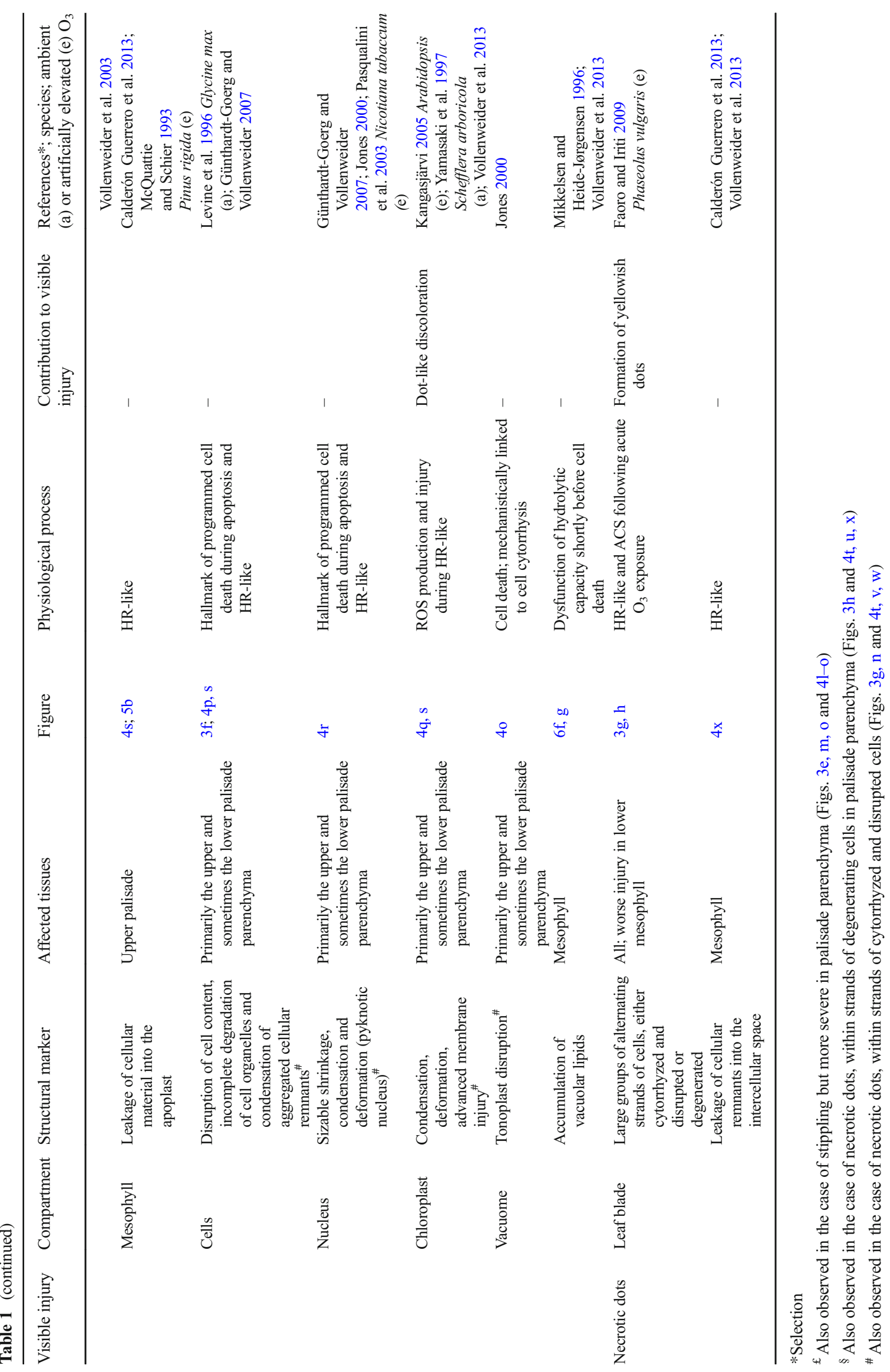


Matyssek et al. 2007; Nunn et al. 2002; Werner and Fabian 2002). The overall outcome from the CASIROZ experiment on tree physiology and growth responses to $\mathrm{O}_{3}$ stress is summarized in Matyssek et al. (2010).

Depending on the regime, yearly ozone levels and environmental conditions, the foliage material sampled between June and September and analysed in this study had been exposed to phytotoxic $\mathrm{O}_{3}$ doses above a threshold of $1 \mathrm{mmol} \mathrm{m}^{-2} \mathrm{~s}^{-1}$ (POD 1) varying between 5 and $36 \mathrm{mmol} \mathrm{m}^{-2}$ (Fig. 1).

\subsection{Leaf injury assessments and microscopy}

At each sampling date (Fig. 1), a leaf sample collection including all $\mathrm{O}_{3}$-like symptom types and asymptomatic material was harvested in the sun crown of beech trees and within both $\mathrm{O}_{3}$ regimes. Hence, we focused on symptom type variability in the most symptomatic part of the canopy, irrespective of each type frequency and recurrence as a function of $\mathrm{O}_{3}$ regime or crown position (microscopic validation approach). In situ, $\mathrm{O}_{3}$ stress effects were diagnosed on the basis of (i) smooth gradients of injury increasing in severity basipetally at branch and leaf levels, (ii) prevalence of injury in foliage (or parts of foliage) exposed to direct solar radiation and (iii) foliar symptoms in the form of leaf discoloration and/or isolated or confluent dark or light stippling (Günthardt-Goerg and Vollenweider 2007; Innes et al. 2001; Schaub et al. 2010). Other types of symptoms incited by various abiotic and biotic stress factors were used for differential diagnosis (Fink 1999; Hartmann et al. 2007; Vollenweider and

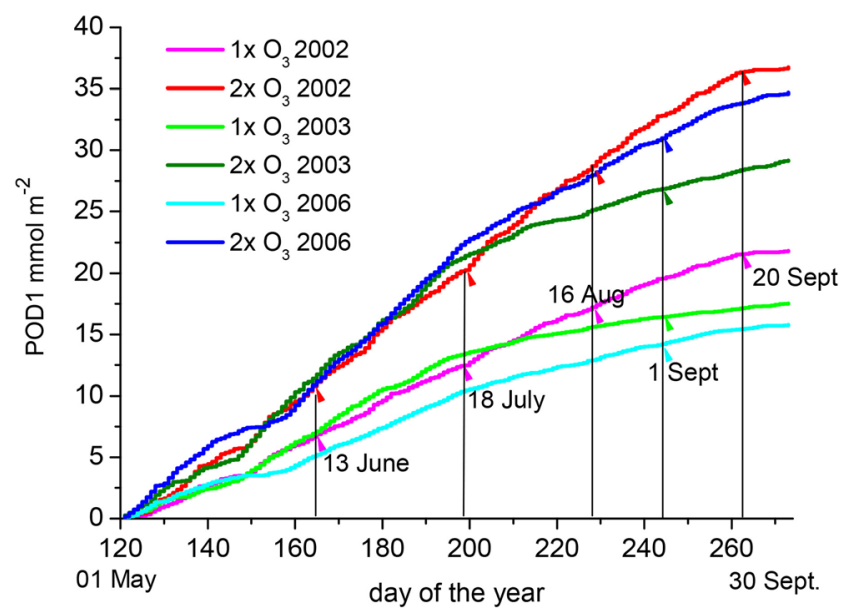

Fig. 1 Cumulated phytotoxic ozone dose (POD1, Grünhage et al. 2012) for beech leaf area during the growing seasons of 2002, 2003 and 2006 (May-September) in the top canopy layer of ambient and twice ambient O3 treatment by a free-air fumigation experiment in Kranzberg Forest, Germany. Arrow heads indicate foliage harvest dates with emphasis on (i) visible $\mathrm{O}_{3}$ symptoms 2002 and 2003, (ii) histochemical analyses of visible symptoms 2003 and (iii) analyses of structural and ultrastructural cell injury 2006
Günthardt-Goerg 2006). After documenting the symptom position and morphology, disc samples were excised, fixed and processed with a view to histochemical, structural and ultrastructural analysis (Moura et al. 2018; Vollenweider et al. 2013). For relating the micro- to macroscopic injury, the position of sections within sampled discs was determined, assessing the location of analysed macro-and microscopic lesions.

\section{Results}

\subsection{Visible injury}

Several types of visible $\mathrm{O}_{3}$-like symptoms, varying between harvests and years, were diagnosed in the upper canopy of beech trees (Fig. 2a). The $\mathrm{O}_{3}$ regimes did not show differences regarding the symptom types. At branch level, the symptoms were distributed along smooth gradients, with their severity increasing basipetally (Fig. 2b). At leaf level, the different types of symptoms included photo-bleaching (Fig. 2e), bronzing (Fig. 2c, e, f), intercostal dark discrete and sometimes confluent stippling (Fig. 2g) and intercostal yellowish dots (Fig. 2h). These symptoms were observed separately (Fig. $2 \mathrm{f}, \mathrm{g}, \mathrm{h}$ ) or in combination (Fig. 2e), primarily on the adaxial and lightexposed leaf sides, whilst shaded leaf parts stayed asymptomatic (Fig. 2e). The yellowish dots formed discrete lesions evenly distributed in the leaf blade and also visible abaxially. In 2003, large intercostal brown flecks, as a consequence of aggregated stippling, were additionally observed (not shown).

\subsection{Microscopic injury underlying discoloration symptoms}

Whatever the symptom type, the most severe structural injury was detected in mesophyll. At tissue level, the mesophyll cells directly underlying symptoms of photobleaching and bronzing showed degenerative changes in comparison to cells in asymptomatic leaf segments (Fig. 3c versus Fig. 3a). Symptoms were more severely expressed adaxially than abaxially (Fig. 3d versus Fig. 31). They included an increase in the condensation of cell content, enlargement of vacuome and accumulation of condensed tannins (bronzing symptoms only), especially within the upper palisade parenchyma cell layer (Fig. 3d versus Fig. 3b). At subcellular level, the cytoplasm and nucleus of mesophyll cells showed a coarser granular structure than in asymptomatic material (Fig. 4f versus Fig. 4a). The matrix and inner membrane system of mitochondria were degraded (Fig. 4i, j versus Fig. 4d, e), whilst chloroplasts showed reduced size, reduced grana 

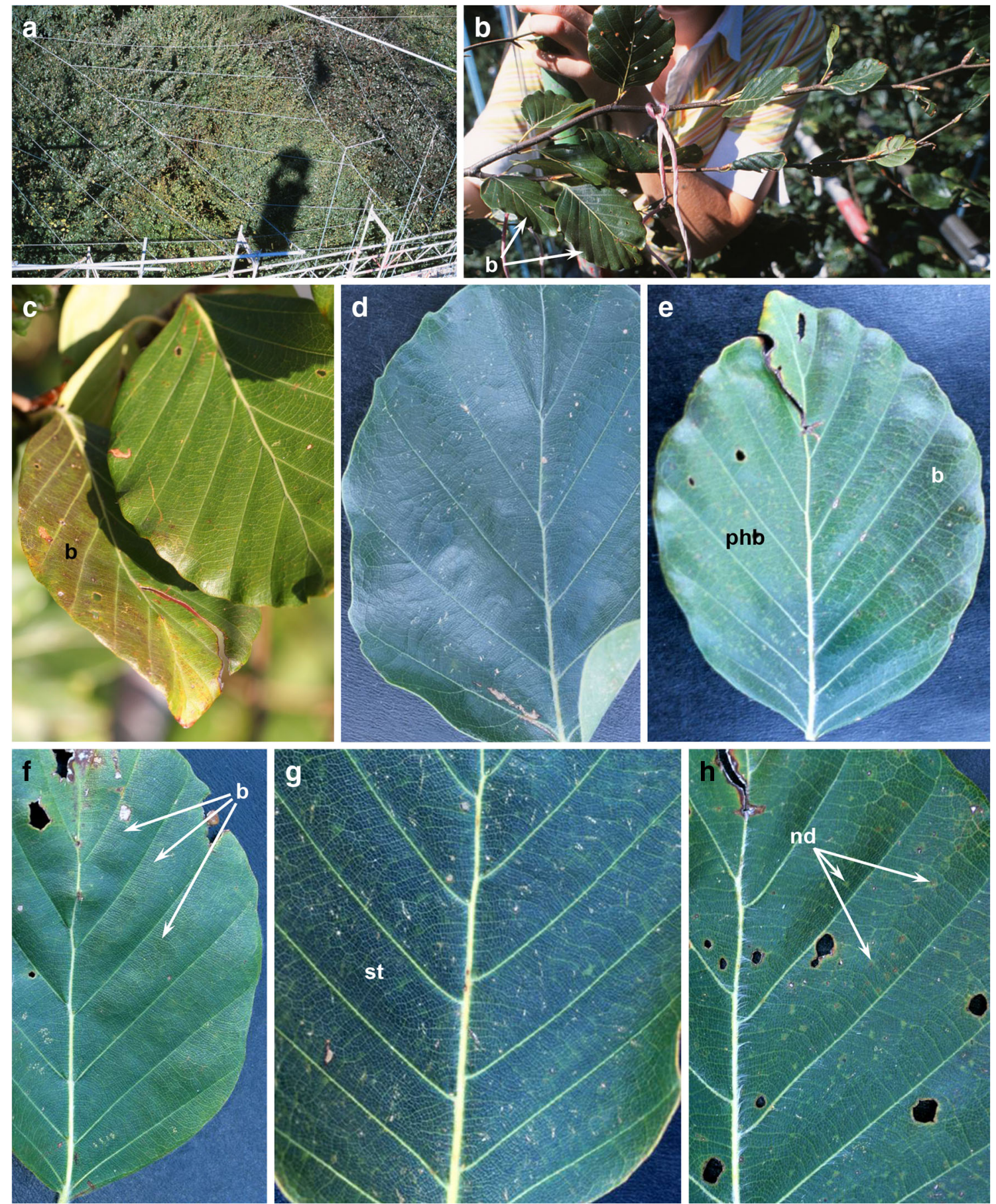

Fig. 2 Visible injury triggered by $\mathrm{O}_{3}$ within foliage of adult beech trees. a Gradients of leaf injury in the canopy, increasing in severity in the better illuminated branches. b Gradients of $\mathrm{O}_{3}$ injury at branch level, increasing

in severity basipetally. $\mathbf{c}-\mathbf{h}$ Singular or combined $\mathrm{O}_{3}$ injury at leaf level: bronzing (b; c, e, f), photobleaching (phb; e), stippling (st; g) and yellowish dots (nd; h). d Asymptomatic

width and increased size and density of plastoglobules (Figs. $3 \mathrm{~d}$ and $4 \mathrm{~g}$, $\mathrm{h}$ versus Figs. $3 \mathrm{~b}$ and $4 \mathrm{~b}, \mathrm{c}$ ). Within the upper palisade cells and with an apparent and concomitant increase in chloroplast illumination, such symptoms were enhanced adaxially (Fig. $4 \mathrm{~g}$ versus Fig. 4h). Plastoglobules, primarily consisting of lipids (Fig. 5a, c), were excreted into the vacuole where they were either degraded, as indicated by undigested rim 
residues, or aggregated into lipid inclusions (Fig. 5d, e). In vacuoles which accumulated condensed tannins, the latter inclusions were found within cavities inside sponge-like solid tannin bodies (Fig. $5 \mathrm{~g}, \mathrm{~h}$ ). Similar but less severe symptoms were observed in spongy parenchyma (Fig. 6g, h versus Fig. 4g-j).

\subsection{Microscopic injury underlying stippling}

Structural injury underlying stippling was more severe than that underlying bronzing and photobleaching (Fig. 3, Table 1). Degenerative symptoms in upper palisade cells were aggravated (Fig. 3e versus Fig. 3c). Besides enhanced condensation and degeneration of organelles (Fig. 4l-o versus Fig. 4g-j), cell death was indicated by cytorrhysis, partial decompartmentation of cell content, tonoplast disruption and shrunken vacuoles (Fig. 4k, o). Vacuoles contained a sizable amount of lipid droplets from excreted plastoglobules. Some of these structures had been leaked into the enlarged intercellular space (Fig. 5b). However, some upper palisade cells lacked any degenerative symptom and only showed structural changes indicative of a hypersensitive reaction-like syndrome (HR-like; Table 1). HR-like markers included (i) cytorrhysis (Figs. $3 \mathrm{f}$ and $4 \mathrm{p}$ ), (ii) disruption of plasmalemma and cell content (Figs. $3 \mathrm{f}$ and $4 \mathrm{p}$, s), (iii) pyknotic nucleus, after condensation, deformation and shrinkage of nucleic material (Fig. 4r), and (iv) condensation and deformation of chloroplasts. These showed disruption of the lamellar system and chloroplast envelope in the absence of an accumulation of plastoglobules (Fig. 4q, s). The peculiar macroscopic stippling injury observed in 2003 was underlain by more severe structural injury than in other years, with larger groups of necrotic cells showing typical HR-like traits, often extending into the lower palisade parenchyma (Fig. 3i, j). Furthermore, spongy parenchyma showed injury similar to that observed in the case of macroscopic bronzing injury (Fig. $3 \mathrm{~m}$, o versus Fig. 31).

\subsection{Microscopic injury underlying yellowish dots}

The structural injury underlying yellowish necrotic dots showed traits differing in several instances from those in the case of bronzing and dark stippling (Table 1). The most severe symptoms were found in the lower mesophyll, where entire tissue segments were necrotic and collapsed and the intracellular space was obstructed by leaked material (Figs. 3g, n and 4x). Within the upper mesophyll, strands of cells showing advanced degeneration alternated with others that were cytorrhyzed and disrupted (Figs. 3h and 4t). Advanced degeneration was indicated by (i) cytoplasm and organelle condensation (Fig. 4u, x), (ii) increase in plastoglobule density (Fig. $4 \mathrm{u}, \mathrm{x})$ and (iii) accumulation of oxidized tannins in the vacuole (Fig. $3 \mathrm{~g}$ ). Besides cytorrhysis (i), the markers of cell death in cytorrhyzed cells included the (ii) disruption of cell content (Figs. 3h and 4t), (iii) nucleus pyknosis (Fig. 4w) and (iv) degradation of the lamellar system and envelope in chloroplasts (Fig. 4v), whereas only a few and small plastoglobules were observed.

\subsection{Microscopic injury in epidermis}

Irrespective of the type of visible injury, symptoms in epidermal cells were generally less severe and less variable than those prevailing in mesophyll (Table 1). The micromorphological markers of oxidative stress in the upper and lower epidermis were similar (Fig. 6c, d versus Fig. $6 \mathrm{j}$ ), but injury was occasionally more severe in the upper epidermis (Fig. 3g, i). At the cell level, the degenerative traits within symptomatic material included the (i) condensation of the cytoplasm (Fig. 6j), (ii) decrease in thylakoid size and apparent enlargement of plastoglobules within leucoplasts (Fig. 6c, d, j), (iii) degeneration of cristae and matrix in mitochondria (Fig. 6d) and (iv) accumulation of condensed tannins (Figs. 3c, g and $6 c, d, j$ ) - but not of lipids (Fig. 5b) - in the vacuole. The less severe injuries, as compared to mesophyll cells, may relate to lower physiological activity, as indicated by the thinner cytoplasm layer, fewer organelles, larger vacuome and flattened and slightly condensed nucleus (Fig. 6a, b, i versus Fig. 6e, f).

\section{Discussion}

\subsection{Visible injury}

Irrespective of the $\mathrm{O}_{3}$ regime, a broad spectrum of visible $\mathrm{O}_{3}$-like symptoms and symptom combinations was observed in the upper canopy of adult beech trees during the 8-year duration of CASIROZ experiment. Photobleaching, bronzing and dark stippling symptoms were typical of oxidative injury by $\mathrm{O}_{3}$ stress in beech. They were similar to evidence (i) reported from field studies (Bussotti and Ferretti 2009; Hůnová et al. 2011; Vollenweider et al. 2003), (ii) reproduced experimentally (Gerosa et al. 2008; Innes et al. 2001; Novak et al. 2003) or (iii) used as hallmarks of $\mathrm{O}_{3}$ injury in beech during monitoring (Günthardt-Goerg 2013; Sanz and Calatayud 2011). Photobleaching symptoms alone lack specificity 
with respect to $\mathrm{O}_{3}$ stress diagnosis (Vollenweider and Günthardt-Goerg 2006). The yellowish dots observed in the two $\mathrm{O}_{3}$ treatments were atypical for beech. Apparent on both leaf sides, they thus showed morphological features contrasting with $\mathrm{O}_{3}$ injury common in broadleaved trees. However, Nunn et al. (2002) reported an apparent increase in the frequency of this symptom under the twice-ambient versus ambient $\mathrm{O}_{3}$ regime. Moreover, light-coloured stipples on the adaxial leaf side can be observed in several broadleaved species, in response to elevated $\mathrm{O}_{3}$ levels (Innes et al. 2001; Sanz and Calatayud 2011). These symptoms also resembled mottling injury in conifers (Miller et al. 1996; Vollenweider et al. 2013). Particularly in the case of yellowish dots and photobleaching, microscopic validation was needed, therefore, to confirm the causal link between $\mathrm{O}_{3}$ stress and morphological traits.

\subsection{Cellular responses to $\mathrm{O}_{3}$ stress responsible for the degenerative changes}

The broad spectrum of microscopic injury (Table 1) was indicative of the several distinct or overlapping plant responses which $\mathrm{O}_{3}$ triggered in foliage of beech trees from the CASIROZ experiment over the 8-year experiment. Whatever the macroscopic symptom type, chloroplast injury was consistently observed as a distinct indication of oxidative stress, even in the case of mild symptoms (Figs. $3 \mathrm{c}, \mathrm{d}$ and $4 \mathrm{f}, \mathrm{g}$ ). The production of reactive oxygen species (ROS) is a side effect of photosynthetic activity and further enhanced in the case of $\mathrm{O}_{3}$ stress (Foyer and Shigeoka 2011; Vainonen and Kangasjärvi 2015). Hence, chloroplasts can show incipient (Desotgiu et al. 2010), severe (Vollenweider et al. 2013) and specific injury (Fink 1999; Günthardt-Goerg and Vollenweider 2007) in response to $\mathrm{O}_{3}$ stress. Given photobleaching and bronzing symptoms, the structural changes in chloroplasts appeared basically similar to those during autumnal senescence in beech leaves (Mikkelsen and Heide-Jørgensen 1996; Tevini and Steinmüller 1985). Consistent with degenerative symptoms in other cell compartments, they denoted, therefore, accelerated cell senescence (ACS; Inada et al. 1998; Vollenweider et al. 2003). Further, the increased amounts of oxidized waste lipids being encapsulated within enlarged plastoglobules and transferred to vacuoles (Fig. 5e) were indicative of enhanced lipid trafficking and thylakoid membrane turnover (Bréhélin et al. 2007; Mikkelsen and Heide-Jørgensen 1996). In the case of milder symptoms, however, lipids did not accumulate in the vacuole, probably in relation to the apparent degradation of excreted plastoglobules. Degenerative changes in epidermal cells (Fig. 6c, d, j) were also indicative of ACS.
Some interactions in the vacuole between lipid excretion mediated by plastoglobules and tannin depositionafter formation within the endoplasmic reticulum (Evert 2006)-may explain the peculiar ultrastructure of sponge-like tannin bodies (Franceschi et al. 1998). When both degradation products were observed in the same vacuolar compartment, the lipids appeared segregated, therefore, within spherical cavities of tannin bodies (Fig. $5 \mathrm{~g}$ ). The cavities showing an electron-translucent content might result from subsequent lipid degradation, whilst the polymerized tannin bodies tended to show cracks but never signs of hydrolysis. Large amounts of condensed tannins can be observed in stressed beech foliage (Bussotti et al. 1998; Günthardt-Goerg and Vollenweider 2007; Oksanen et al. 2001), and, together with increasing tannin oxidation adaxially, they form hallmarks of $\mathrm{O}_{3}$ stress (Calderón Guerrero et al. 2013; Hartmann et al. 2007; Vollenweider et al. 2003). Similar to other intraand intercellular gradients of oxidative injury within the studied material (Figs. $3 \mathrm{c}$ and $4 \mathrm{k}$ ), such markers were indicative of synergistic effects of $\mathrm{O}_{3}$ and photooxidative stress (Foyer et al. 1994; Günthardt-Goerg and Vollenweider 2007), as they contributed to visible symptom expression.

\subsection{Contrast between degenerative and disruptive traits underlying stippling symptoms}

The observation of cell degeneration together with cell death markers within the same mesophyll cells (Fig. 4k) was indicative of the occasional overlap of ACS and HR-

Fig. 3 Tissue- and cell-level changes caused by oxidative stress within foliage of beech trees. Changes in segments of leaf blades underlying bronzing (c, d, l), stippling (e, f, i, j, m, o) and yellowish dots $(\mathbf{g}, \mathbf{h}, \mathbf{n})$ versus asymptomatic material $(\mathbf{a}, \mathbf{b}, \mathbf{k})$. Bronzing symptoms $(\mathbf{c}, \mathbf{d})$ : condensed tannins inside vacuoles of upper epidermis (UE, blue) and palisade parenchyma (PP), sometimes in the form of plugs (*), condensation of cytoplasm (c) and nucleus (n), decrease in chloroplast (ch) size and increase in plastoglobule (pg) size and frequency. Stippling symptoms (e, $\mathbf{f}, \mathbf{i}, \mathbf{j}, \mathbf{m}, \mathbf{o}$ ): changes observed in the case of bronzing interspersed with dead, disrupted and partly cytorrhyzed cells in upper palisade parenchyma (e, f); groups of cytorrhyzed, disrupted and condensed (\#) cells extending into lower palisade, in the case of stronger reactions $(2003 ; \mathbf{i}, \mathbf{j})$. Less injury in spongy parenchyma (SP) and lower epidermis (LE; $\mathbf{l}, \mathbf{m}, \mathbf{o})$. Yellowish dots $(\mathbf{g}, \mathbf{h}, \mathbf{n})$ : injury by oxidative stress more severe in abaxial than adaxial tissues, with parts of lower mesophyll disrupted and the cells cytorrhyzed $(\& ; \mathbf{g})$. Lesions consisting of cell strands either collapsed and condensed (\#) or deformed and degenerated $(\S ; \mathbf{h})$ and containing oxidized condensed tannins (oct; $\mathbf{g}, \mathbf{h}$ ). Leakage of cell debris in the intercellular space (is) of lower leaf blade (n). Other structures: st: starch, oct: oxidized condensed tannins. Technical specifications: staining with Toluidine blue and $p$-phenylenediamine, observation in bright field microscopy (a, c, e, g, i), using phase contrast $(\mathbf{b}, \mathbf{d}, \mathbf{f}, \mathbf{h}, \mathbf{j}-\mathbf{0})$ 


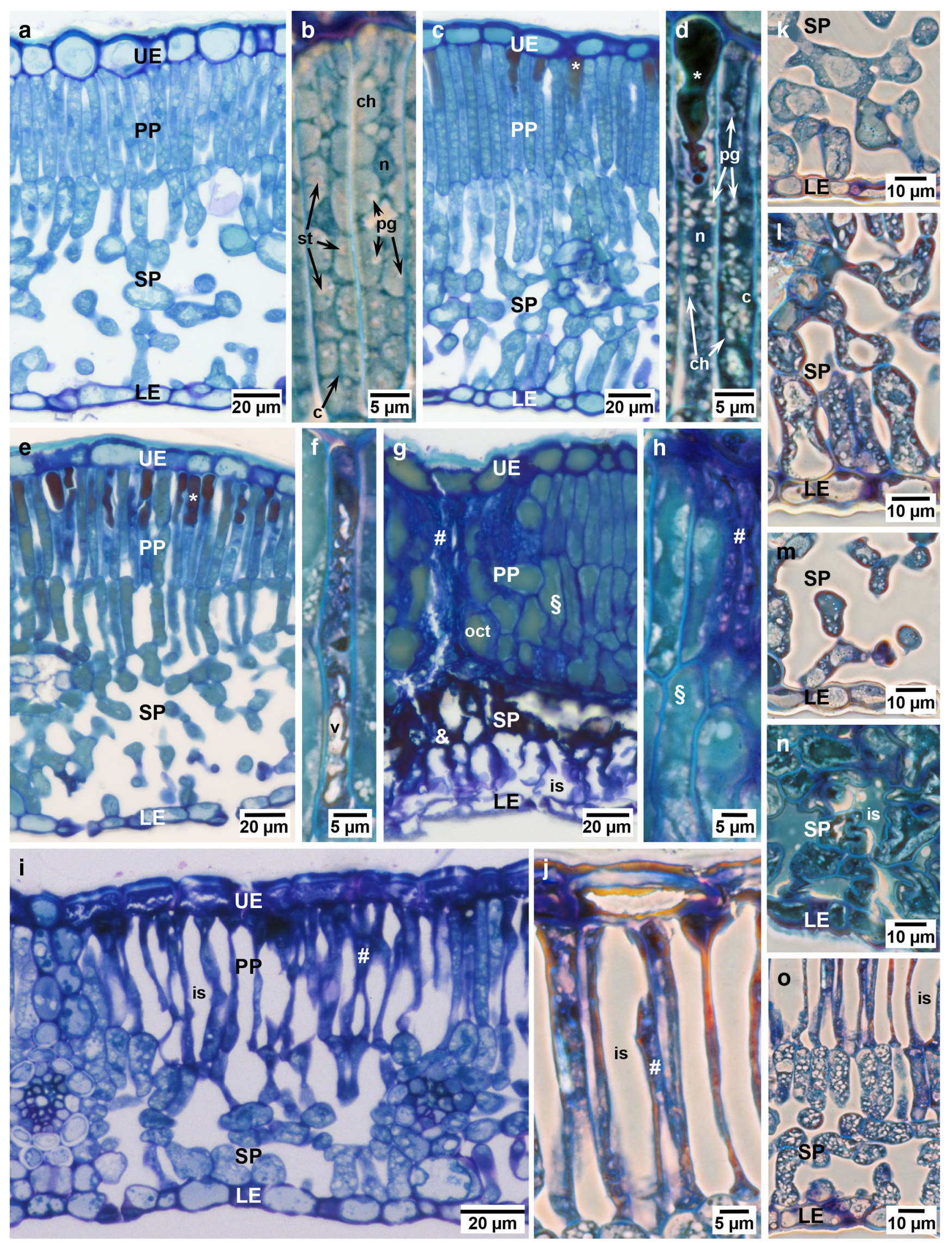




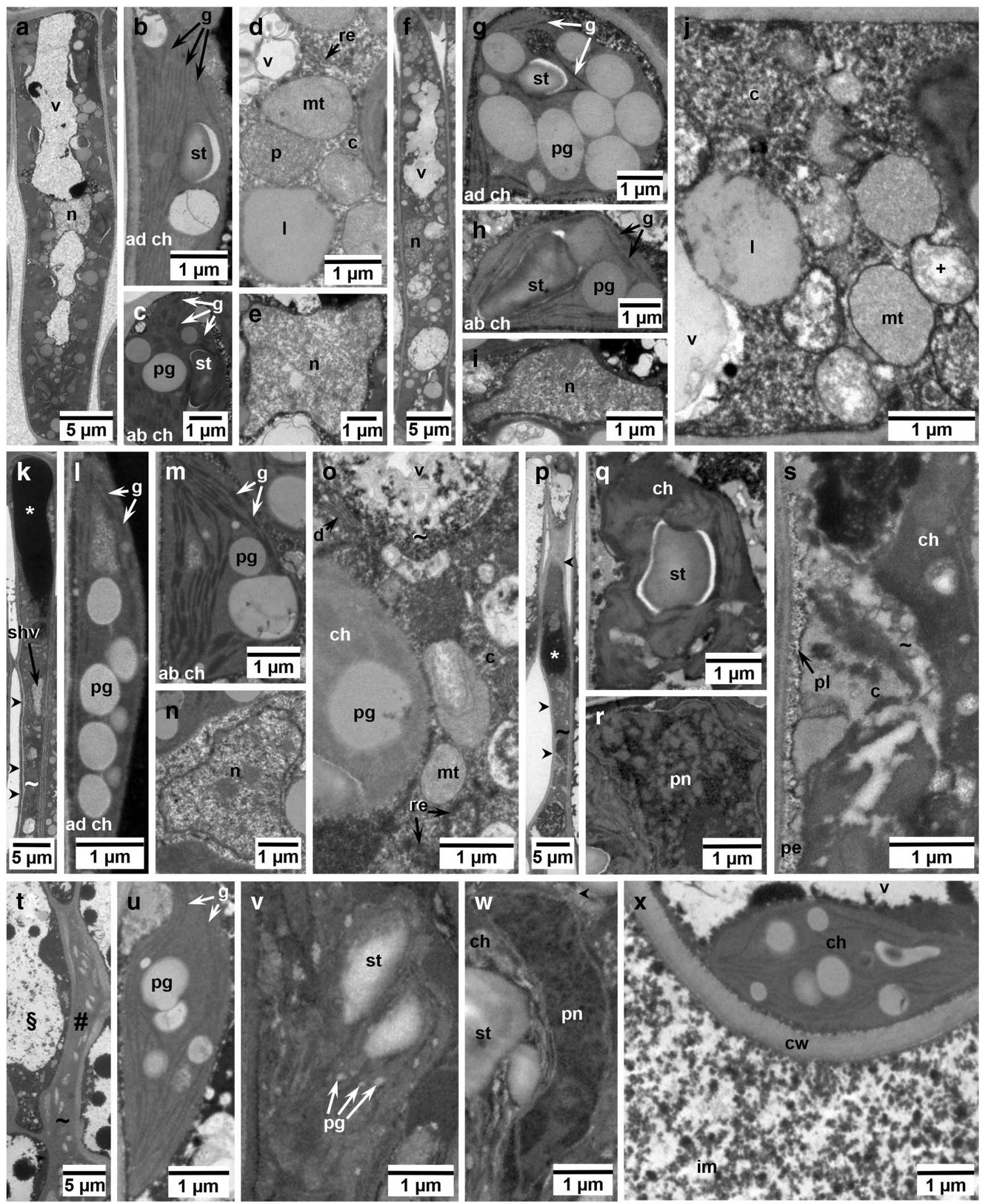

like processes within stippling symptoms. Whilst ACS progressively develops during the growing season (Pell et al. 1997), the HR-like processes are triggered once an oxidative stress threshold has been exceeded, causing

\section{פQ Spriagr}


Fig. 4 Cellular and subcellular changes caused by oxidative stress within foliage of beech trees. Changes within palisade cells underlying bronzing $(\mathbf{f}-\mathbf{j})$, stippling $(\mathbf{k}-\mathbf{s})$ and yellowish dots $(\mathbf{t}-\mathbf{x})$ versus asymptomatic material (a-e). Bronzing symptoms $(\mathbf{f}-\mathbf{j})$ : the adaxial chloroplasts (ad $\mathrm{ch}, \mathbf{g})$ contained more plastoglobules (pg) but fewer grana than abaxial organelles (ab ch, h). Plastoglobules were larger and grana stacks smaller. Nucleus (n) content was condensed and its envelope electron-opaque (i). j condensed cytosol (c) and injured matrix and inner membrane system (+) within the mitochondria $(\mathrm{mt})$. Stippling symptoms $(\mathbf{k}-\mathbf{s})$ : the severity of degenerative traits in chloroplasts $(\mathbf{l}, \mathbf{m})$, nucleus $(\mathbf{n})$ and cytoplasm (o) was enhanced. $\mathbf{k}$ Fewer chloroplasts adaxially and vacuole filled with oxidized tannin bodies (*) often plugging the adaxial cell lumen. Occasionally, partial cell decompartmentation $(\sim)$, shrinking vacuoles (shv) and cytorrhysis (arrowheads) indicated terminal cell degeneration and cell death. HR-like traits (p-s): cells were cytorrhyzed (arrowheads) and their content disrupted $(\mathbf{p})$, chloroplasts $(\mathbf{q}, \mathbf{s})$ together with other organelles and cell structures (s) condensed and deformed, and extensive membrane damage was indicated by poor membrane resolution. Some material had been leaked into the periplasm (pe) through ruptured plasmalemma (pl). r Pyknotic nucleus showing deformation and acute chromatin condensation. Yellowish dots $(\mathbf{t}-\mathbf{x})$ : cytorrhyzed and condensed (\#) versus deformed and degenerated $(\S)$ strands $(\mathbf{t})$. Within the latter group of cells $(\S ; \mathbf{u}, \mathbf{x})$, the chloroplasts showed degenerative traits (i.e. thinner grana and higher plastoglobule density). Within the former group of cells (\#; v, w), the chloroplasts were condensed and deformed, their grana poorly resolved and the plastoglobules still small. w Pyknotic nucleus. x Intercellular material (im) leaked from adjacent dead cells. Other structures: cw: cell wall, d: dictyosome, 1: lipid droplet, re: smooth endoplasmic reticulum, st: starch, v: vacuole. Technical specifications: postfixation using $\mathrm{OsO}_{4}$, contrasting using uranyl acetate and lead citrate, observation in TEM

rapid cell death soon thereafter (Calderón Guerrero et al. 2013; Rao and Davis 2001). In chloroplasts of some cells exhibiting HR-like traits (Fig. 4q), missing degenerative features, such as large and numerous plastoglobules (Lichtenthaler 2013), thus suggested cell death early in the growing season. The disrupted cellular material further contrasted with such undergoing degenerative changes by showing deformation and coagulation, whilst the inner and outer membrane systems were fused, broken or partially hydrolysed (Fig. 4s). Other HR-like hallmarks included nuclear pyknosis (Fig. 4r; Jones 2000; Pasqualini et al. 2003) and incomplete degradation of cellular residues (Fig. 4s; Fukuda 2000). Major injury to cell walls, as observed in other cases of HR-like processes triggered by $\mathrm{O}_{3}$ stress (Calderón Guerrero et al. 2013; Paoletti et al. 2010; Vollenweider et al. 2013), was indicated by leakage of cellular material into the apoplast (Fig. 5b). Regarding the aforementioned accumulation of lipids, and in the case of inclusions contiguous to incompletely degraded structures within dead cells (Figs. $4 \mathrm{f}$ and $5 \mathrm{~d}$ ), our observations suggest a decrease in the hydrolytic capacity of vacuoles shortly before cell death. Disruption of the latter hydrolytic compartment forms a terminal degeneration stage of cell content during senescence (Inada et al. 1998). In contrast to ACS, vacuole disruption preceded-maybe impeded-full cell content degradation in the case of HR-like events (Fig. $3 \mathrm{j}$ and $4 \mathrm{k}$ ), which might represent a benchmark trait to differentiate between the slow ACS degeneration process and the quick HR-like cell death.

\subsection{Structural indications of $\mathrm{O}_{3}$ injury in yellowish dots}

Underlying necrotic dots (Fig. $3 \mathrm{~g}, \mathrm{~h}, \mathrm{n}$ ), strands of cells, either degenerated or disrupted, indicated typical contrasts between ACS or HR-like processes. The absence synergism with photo-oxidative stress effects, together with major injury next to stomata in tissues of the lower leaf blade, suggests oxidative injury by $\mathrm{O}_{3}$ stress alone. Owing to the tissue arrangement within needles, mottling injury by $\mathrm{O}_{3}$ stress in pines is generally closely associated with stomata (Evans and Miller 1972; Soda et al. 2000; Vollenweider et al. 2013). In angiosperms, cell death primarily within the lower mesophyll in response to $\mathrm{O}_{3}$ stress has been observed after exposure to high $\mathrm{O}_{3}$ concentrations (150 ppb; Faoro and Iriti 2005; Pasqualini et al. 2003). The indications of severe $\mathrm{O}_{3}$ stress leading to rapid cell death included (i) necrotic cells also in upper mesophyll (Fig. 3g), (ii) massive leakage of cell debris (Fig. 5b) or (iii) small plastoglobules inside chloroplasts (Fig. 4v). Hence, the singular structural traits underlying the yellowish dots suggest origin from acute $\mathrm{O}_{3}$ stress and locally high $\mathrm{O}_{3}$ concentrations. The severity of injuries peaking in the lower mesophyll also explains that the symptoms become visible on both leaf sides.

\subsection{Variability of structural $\mathrm{O}_{3}$ injury in relation to $\mathrm{O}_{3}$ uptake}

The variability of visible macroscopic symptoms, underlying microscopic injury and cellular responses to $\mathrm{O}_{3}$ stress observed during the CASIROZ long-term experiment, provided insights on the dependency of macroand microscopic symptoms by the end of the growing season on the seasonal ozone uptake (Fig. 7). Closely assigning the microscopic injury to visible symptoms during microscopic analyses, the precedence of microscale injury became evident, as macro-scale visibility emerged only once a sizable group of cells had been affected. The concomitance of degenerative and disruptive traits within the same cells can only be understood in terms of a succession, with ACS progressing until a species-specific threshold is reached, so that HR-like processes are triggered, which incite the rapid cell death. In 2003, this succession occurred at an earlier date, as indicated by the low accumulation of tannins and tannin plugs in the mesophyll (Fig. 3i, j). In the case of massive $\mathrm{O}_{3}$ dose, structural injury should mainly relate to HR-like 

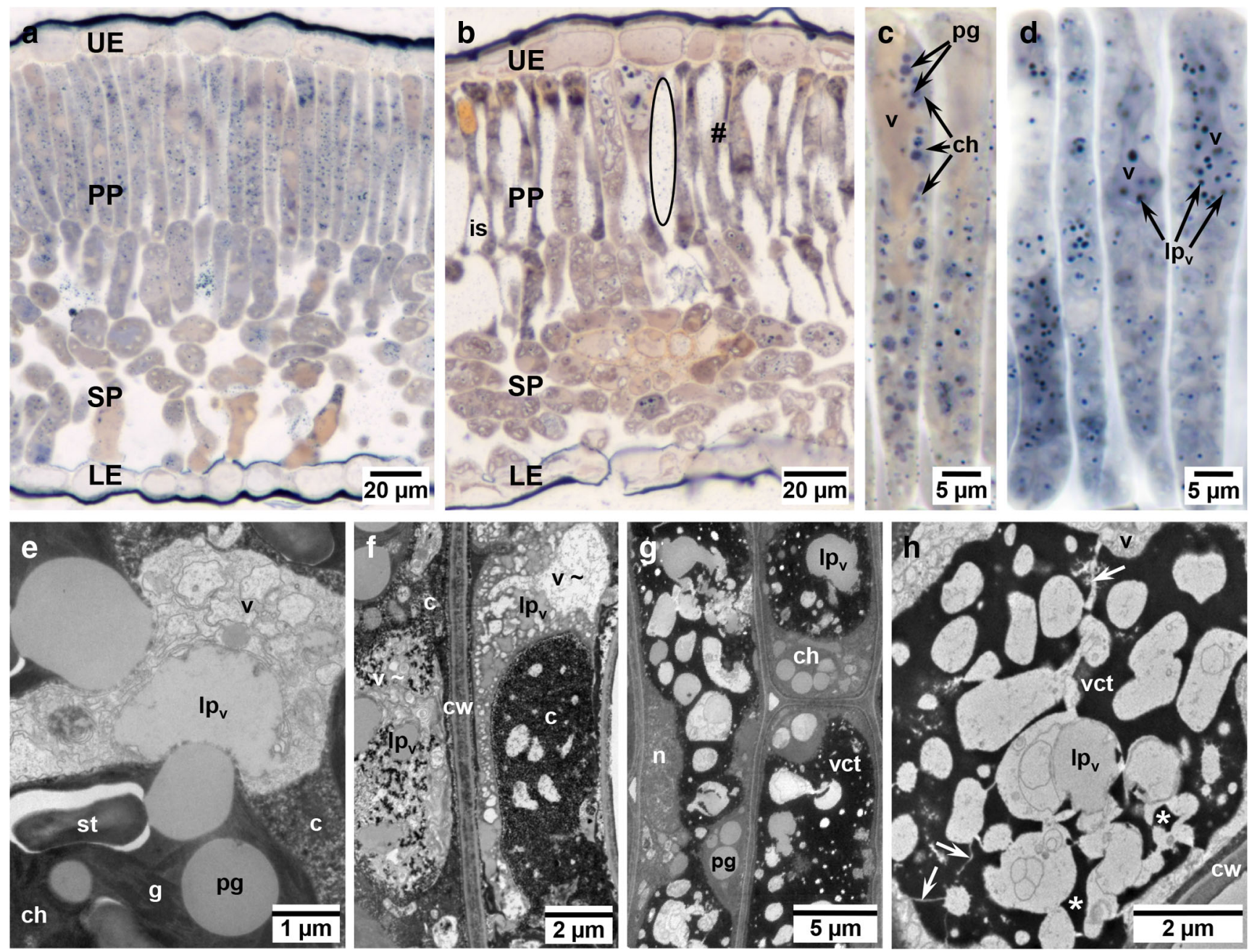

Fig. 5 Contribution of plastoglobules to the accumulation of vacuolar lipids. a Accumulation of plastoglobules (in blue) in degenerating cells from palisade (PP) and spongy (SP) parenchyma. b Within stippling symptoms, lipids (encircled) were leaked into the enlarged intercellular spaces (is) between disrupted and cytorrhyzed cells (\#). c Accumulation of large plastoglobules within chloroplasts $(\mathrm{ch})$ from palisade parenchyma cells in leaves showing bronzing symptoms. d Accumulation of vacuolar lipid $\left(\mathrm{lp}_{\mathrm{v}}\right)$ after apparent excretion of plastoglobules into the vacuole. $\mathbf{e}-\mathbf{h}$ Plastoglobule excretion and fate in the vacuole. $\mathbf{e}$ The plastoglobules excreted from chloroplasts into vacuoles (v) had their lipids apparently degraded, with an outer shrunken ring as the only remnant. $\mathbf{f}$ Accumulation of vacuolar lipids shortly before cell death within

disrupting vacuoles $(\mathrm{v} \sim)$. g Simultaneous accumulation of plastoglobules and condensed tannin (vct) in the vacuole, with lipids filling globular cavities within and gaps between tannin deposits. $\mathbf{h}$ Contiguous arrangement of lipids and tannins in the vacuole. The polymerization of condensed tannins in solid bodies was indicated by splits (arrows) and broken pieces $(*)$. The vacuolar lipids formed globular deposits, sometimes encapsulated within tannin bodies and showing evidence of degradation. Other structures: c: cytoplasm; cw: cell wall; g: grana; LE: lower epidermis; n: nucleus; st: starch; UE: upper epidermis. Technical specifications: histochemical revelation of lipids using Sudan Black B (a-d), TEM as in Fig. $3(\mathbf{e}-\mathbf{h})$

processes. The visible symptom progression commonly observed in the field, with photobleaching symptoms sometimes in summer prior to discoloration and subsequent stippling appears (authors' unpublished observations) can also be conceptually understood in terms of succeeding ACS and HR-like processes. Hence, by the end of the vegetation season, when most observations of ozone symptoms are realized in the field (Schaub et al. 2010), the symptom types and macro- and micromorphology traits will synthetically reflect the reactions and cellular responses to the experienced ozone dose.

\section{Conclusion}

In the CASIROZ experiment, a large spectrum of typical as well as atypical $\mathrm{O}_{3}$ macroscopic and microscopic injury was observed during the 8-year period. Variation was encountered especially regarding the microscopic markers of $\mathrm{O}_{3}$ stress from year to year. This variability primarily related to (i) ACS and HR-like plant responses either distinct or overlapping, (ii) interaction between $\mathrm{O}_{3}$ and

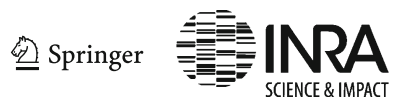



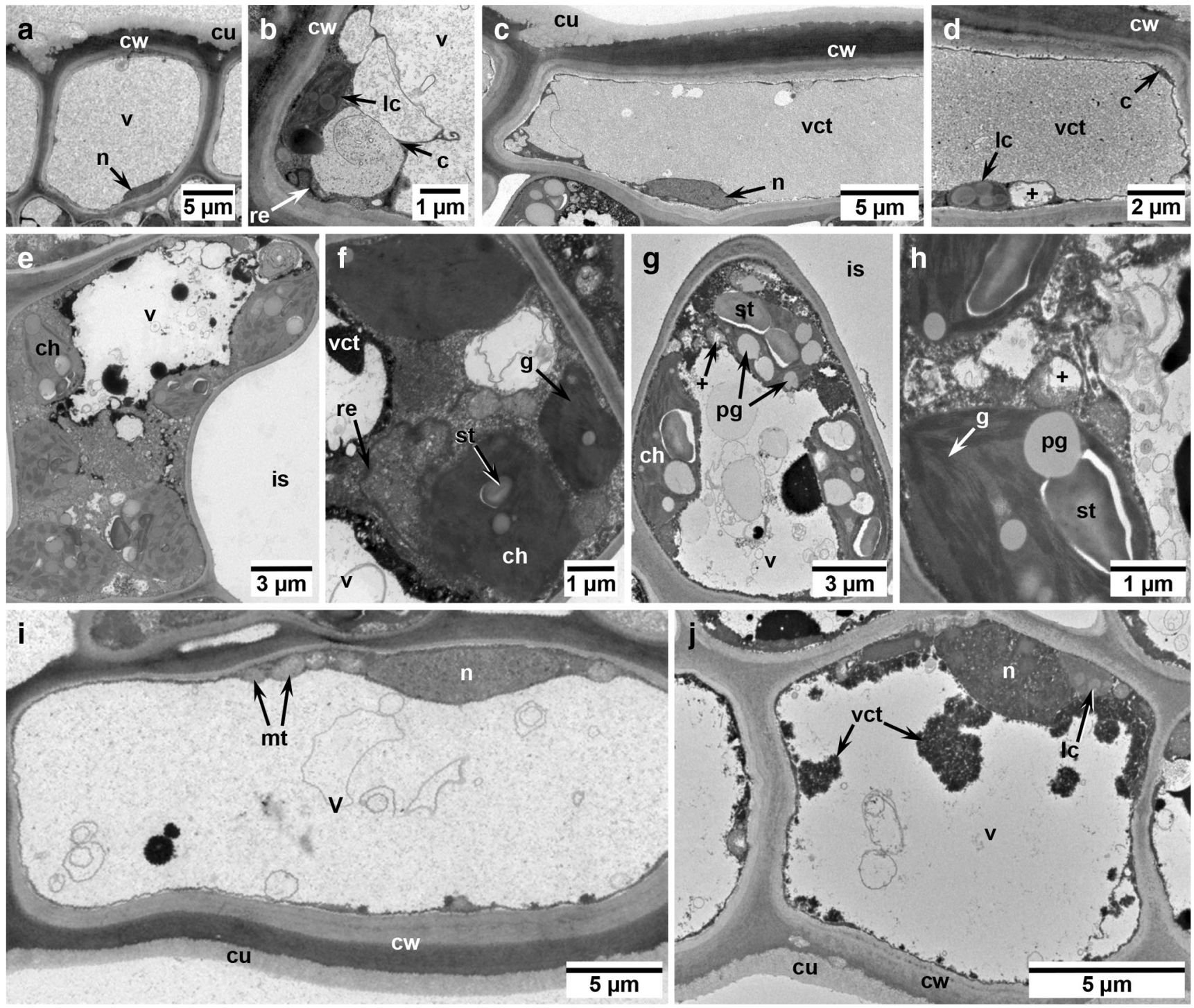

$5 \mu \mathrm{m}$

Fig. 6 Cellular and subcellular changes caused by oxidative stress in the upper epidermis (a-d), spongy parenchyma $(\mathbf{e}-\mathbf{h})$ and lower epidermis (i-j) of symptomatic $(\mathbf{c}, \mathbf{d}, \mathbf{g}, \mathbf{h}, \mathbf{j})$ versus asymptomatic $(\mathbf{a}, \mathbf{b}, \mathbf{e}, \mathbf{f}, \mathbf{i})$ foliage material. Degenerative changes were indicated by the condensation of cytoplasm (c), decrease of thylakoids and increase of plastoglobules within leucoplasts (lc) or chloroplasts (ch), injury (+) to cristae and matrix of mitochondria (mt) and accumulation of condensed

photo-oxidative stress and (iii) yearly variation in $\mathrm{O}_{3}$ dose and uptake rates. Especially traits of degeneration and disruption showed contrasted structural features. Concerning stippling symptoms, the structural variability was particularly high, as a consequence of interacting ACS and HR-like responses and the initiation of programmed cell death at different times of growing season. Hence, the expression of macroscopic and microscopic symptoms by the end of summer can provide an integrative view of successive plant responses and symptom tannins (vct) in the vacuole (v). Notice the lower physiological activity in
the asymptomatic epidermis $(\mathbf{a}, \mathbf{b}, \mathbf{i})$ versus spongy parenchyma $(\mathbf{e}, \mathbf{f})$, as indicated by the thinner cytoplasm layer, few organelles, larger vacuome and more condensed nucleus structure (n). Other structures: cu: cuticle; cw: cell wall; g: grana; is: intercellular space; re: smooth endoplasmic reticulum, st: starch, v: vacuole. Technical specifications: TEM as in Fig. 3

development during the preceding course of the growing season. The difficulties posed by the symptom variability can be alleviated conceptually, when relating the injuries observed at different scales to the experienced ozone dose and environmental conditions. Within a changing climate and ozone pollution context, farther variability of $\mathrm{O}_{3}$ injury in trees can be expected. Based on the present observations, symptom variability will nevertheless arise from shifting prevalence of typical $\mathrm{O}_{3}$-induced responses and prominent structural markers, as observed so far. 


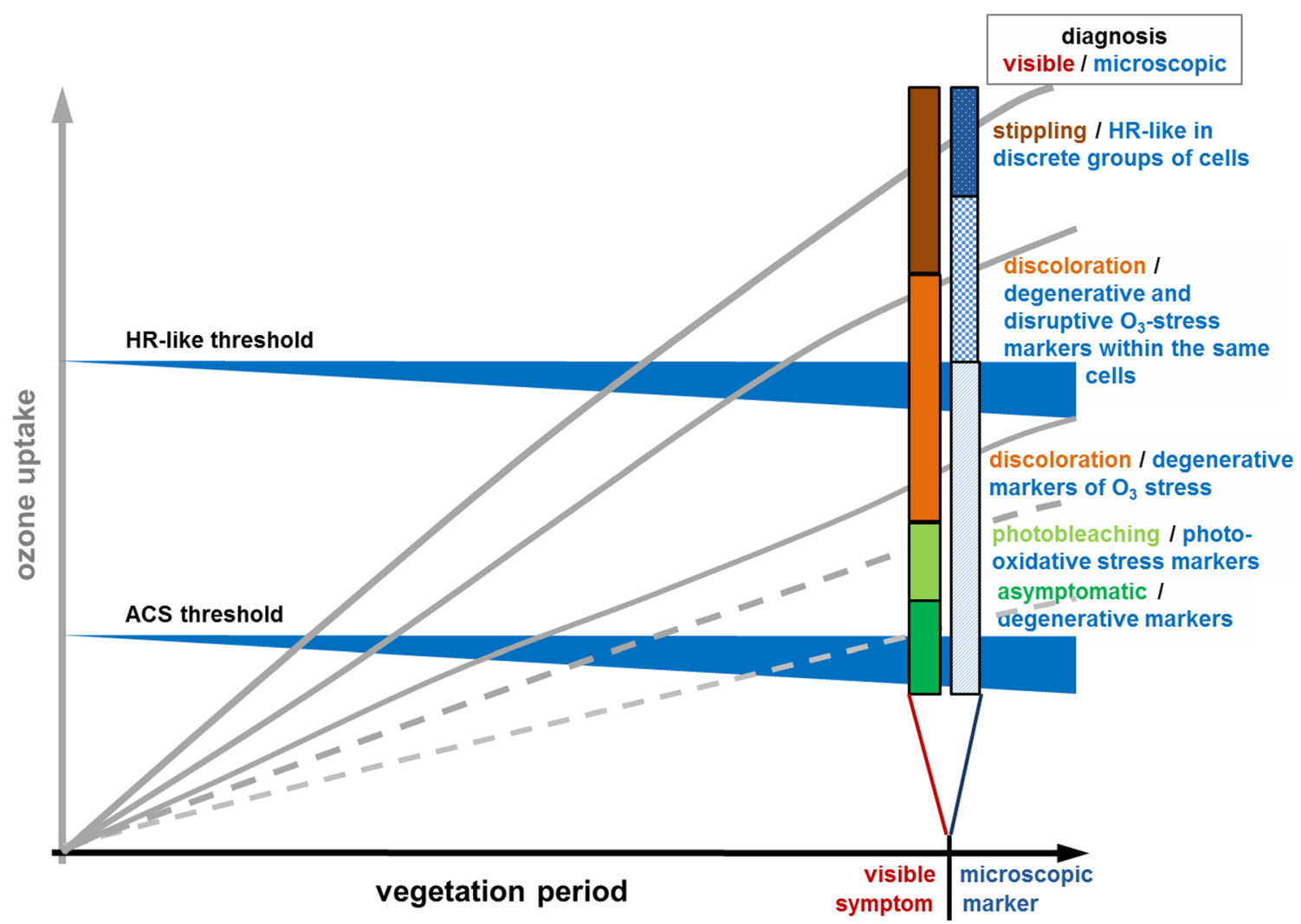

Fig. 7 Conceptual model of $\mathrm{O}_{3}$ injury variation by the end of vegetation season and in relation to $\mathrm{O}_{3}$ uptake. The spectrum of visible symptoms and microscopic markers of $\mathrm{O}_{3}$ stress late in the vegetation season depends on the yearly $\mathrm{O}_{3}$ uptake (each grey line). Degenerative or disruptive microscopic injury appears at lower $\mathrm{O}_{3}$ dose than the overlying visible symptoms. The term discoloration indicates a change in foliage hue or colour (e.g. photobleaching or bronzing, reddening) as a consequence of chlorophyll degradation or accumulation of compounds from the secondary metabolism. The induction of cellular responses (ACS, HR-like) depends on the species-specific exceedance of $\mathrm{O}_{3}$ uptake threshold, tending to more variable values later in the vegetation season as a consequence of varying foliage phenology. Application range: broadleaved trees and shrubs in temperate and tropical biomes
Acknowledgements Technical assistance and support by $\mathrm{PhD}$ students, trainees and microscopy apprentices (sampling and characterization of visible and microscopic injury) and the Center for Microscopy and Image Analysis of the University of Zürich (electron microscopy) are gratefully acknowledged. Sampling in 2002 and 2003 by the PhD students Angela Nunn, Nina Koch and Markus Löw, technical assistance by trainees and microscopy apprentices and the Center for Microscopy and Image Analysis of the University of Zürich (transmission electron microscopy) are gratefully acknowledged.

Funding The CASIROZ (Carbon Sink Strength of Beech in a Changing Environment: Experimental Risk Assessment of Mitigation by Chronic Ozone Impact) research project (face $\mathrm{O}_{3}$ fumigation in the Kranzberg forest) was supported by the European Commission - Research Directorate-General, Environment Programme, "Natural Resources Management and Services" (EVK2-2002-00165, Ecosystem Vulnerability). Further support was provided by the German Research Foundation (DFG) through SFB 607 "Growth and Parasite Defense Competition for Resources in Economic Plants from Agronomy and Forestry".

Data availability More than 1000 pictures from this study are part of the WSL database and are available from the corresponding author on reasonable request.

\section{Compliance with ethical standards}

Conflicts of interest The authors declare that there are no competing interests.

\section{References}

Alvarez D, Laguna G, Rosas I (1998) Macroscopic and microscopic symptoms in Abies religiosa exposed to ozone in a forest near Mexico City. Environ Pollut 103:251-259

Alves ES, Moura BB, Pedroso ANV, Tresmondi F, Machado SR (2016) Cellular markers indicative of ozone stress on bioindicator plants growing in a tropical environment. Ecol Indic 67:417-424

Baumgarten M, Huber C, Büker P, Emberson L, Dietrich H-P, Nunn AJ, Heerdt C, Beudert B, Matyssek R (2009) Are Bavarian forests (southern Germany) at risk from ground-level ozone? Assessment using exposure and flux based ozone indices. Environ Pollut 157: 2091-2107

Bréhélin C, Kessler F, van Wijk KJ (2007) Plastoglobules: versatile lipoprotein particles in plastids. Trends Plant Sci 12:260-266 
Bussotti F, Ferretti M (2009) Visible injury, crown condition, and growth responses of selected Italian forests in relation to ozone exposure. Environ Pollut 157:1427-1437

Bussotti F, Gravano E, Grossoni P, Tani C (1998) Occurrence of tannins in leaves of beech trees (Fagus sylvatica) along an ecological gradient, detected by histochemical and ultrastructural analyses. New Phytol 138:469-479

Bussotti F, Agati G, Desotgiu R, Matteini P, Tani C (2005) Ozone foliar symptoms in woody plant species assessed with ultrastructural and fluorescence analysis. New Phytol 166:941-955

Bytnerowicz A, Fenn M, McNulty S, Yuan F, Pourmokhtarian A, Driscoll C, Meixner T (2013) Interactive effects of air pollution and climate change on forest ecosystems in the United States: current understanding and future scenarios. In: Matyssek R, Clarke N, Cudlin P, Mikkelsen TN, Tuovinen JP, Wieser G, Paoletti E (eds) Climate Change, Air Pollution and Global Challenges: Understanding and Perspectives from Forest Research. Book series: Dev Environ Sci 13: 333-369

Cristofori A, Bacaro G, Confalonieri M, Cristofolini F, Frati L, Geri F, Gottardini E, Tonidandel G, Zottele F, Ferretti M (2015) Estimating ozone risks using forest monitoring networks-results for science, policy, and society. Ann For Sci 72:887-896

Dai L, Li P, Shang B, Liu S, Yang A, Wang Y (2017) Differential response of peach (Prunus persica) seedlings to elevated ozone are related with leaf mass per area, antioxidant enzymes activity rather than stomatal conductance. Environ Pollut 227:380-388

Desotgiu R, Bussotti F, Faoro F, Iriti M, Agati G, Marzuoli R, Gerosa G, Tani C (2010) Early events in populus hybrid and Fagus sylvatica leaves exposed to ozone. The Sci world J 10:512-527

Evans LS, Miller PR (1972) Comparative needle anatomy and relative ozone sensitivity of four pine species. Can J Bot 50:1067-1071

Evert RE (2006) Esau's plant anatomy. Wiley, Hoboken

Faoro F, Iriti M (2005) Cell death behind invisible symptoms: early diagnosis of ozone injury. Biol Plant 49:585-592

Faoro F, Iriti M (2009) Plant cell death and cellular alterations induced by ozone: key studies in Mediterranean conditions. Environ Pollut 157: 1470-1477

Ferretti M, Sanders T, Michel A, Calatayud V, Cools N, Gottadini E, Häni M, Hansen K, Potočić N, Schaub M, Timmermann V, Trotzer S, Vanguelova E (2015) ICP Forests Executive Report 2014. The impact of nitrogen deposition and ozone on the sustainability of European forests. Thünen Institute of Forest Ecosystems, Eberswalde, Germany, pp. 29, e-ISSN 2198-6541

Fink S (1999) Pathological and regenerative plant anatomy. Encyclopedia of plant anatomy, vol XIV/6. Gebrüder Bornträger, Berlin, Stuttgart, $\mathrm{p}$ 1095

Foyer CH, Shigeoka S (2011) Understanding oxidative stress and antioxidant functions to enhance photosynthesis. Plant Physiol 155:93-100

Foyer CH, Lelandais M, Kunert KJ (1994) Photooxidative stress in plants. Physiol Plant 92:696-771

Franceschi VR, Krekling T, Berryman AA, Christiansen E (1998) Specialized phloem parenchyma cells in Norway spruce (Pinaceae) bark are an important site of defense reactions. Am J Bot 85:601-615

Fuhrer J, Val Martin M, Mills G, Heald CL, Harmes H, Hayes F, Sharps K, Bender J, Ashmore MR (2016) Current and future ozone risks to global terrestrial biodiversity and ecosystem processes. Ecol Evol 6: $8785-8799$

Fukuda H (2000) Programmed cell death of tracheary elements as a paradigm in plants. Plant Mol Biol 44:245-253

Garthwaite R, Fowler D, Stevenson D, Cox P, Ashmore M, Grennfelt P, Amann M, Anderson R, Depledge M, Derwent D, Hewitt N, Hov O, Jenkin M, Kelly F, Liss P, Pilling M, Pyle J, Slingo J (2009) Ground level ozone in the 21st century: trends, interactions with climate and environmental impacts. IOP Conference Series. Earth Environ Sci 6(28):282002, 3 pp. https://doi.org/10.1088/1755-1307/6/28/282002
Gerosa G, Marzuoli R, Desotgiu R, Bussotti F, Ballarin-Denti A (2008) Visible leaf injury in young trees of Fagus sylvatica L. and Quercus robur $\mathrm{L}$. in relation to ozone uptake and ozone exposure. An opentop chambers experiment in South Alpine environmental conditions. Environ Pollut 152:274-284

Gravano E, Bussott F, Strasser RJ, Schaub M, Novak K, Skelly J, Tani C (2004) Ozone symptoms in leaves of woody plants in open-top chambers: ultrastructural and physiological characteristics. Physiol Plant 121:620-633

Grünhage L, Matyssek R, Häberle KH, Wieser G, Metzger U, Leuchner M, Menzel A, Dieler J, Pretzsch H, Grimmeisen W, Zimmermann L, Raspe S (2012) Flux-based ozone risk assessment for adult beech forests. Trees Struct Func 26:1713-1721

Calderón Guerrero C, Günthardt-Goerg MS, Vollenweider P (2013) Foliar symptoms triggered by ozone stress in irrigated holm oaks from the city of Madrid, Spain. PLoS One 8(7):e69171. https://doi. org/10.1371/journal.pone.0069171

Günthardt-Goerg MS (2013) https:/www.waldwissen.net/wald/klima/ immissionen/wsl_fotodokumentation_ozonsymptome/index_DE. Assessed 31 October 2018)

Günthardt-Goerg MS, Vollenweider P (2007) Linking stress with macroscopic and microscopic leaf response in trees: new diagnostic perspectives. Environ Pollut 147:467-488

Günthardt-Goerg MS, McQuattie CJ, Maurer S, Frey B (2000) Visible and microscopic injury in leaves of five deciduous tree species related to current critical ozone levels. Environ Pollut 109:489-500

Harmens H, Hayes F, Sharps K, Mills G, Calatayud V (2017) Leaf traits and photosynthetic responses of Betula pendula saplings to a range of ground-level ozone concentrations at a range of nitrogen loads. J Plant Physiol 211:42-52

Hartmann G, Nienhaus F, Butin H (2007) Farbatlas Waldschäden. Diagnose von Baumkrankheiten. 3. Auflage. Eugen Ulmer KG, Stuttgart, pp. 269

Holopainen T, Anttonen S, Palomäki V, Kainulainen P, Holopainen JK (1996) Needle ultrastructure and starch content in Scots pine and Norway spruce after ozone fumigation. Can J Bot 74:67-76

Hůnová I, Matoušková L, Srněnský R, Koželková K (2011) Ozone influence on native vegetation in the Jizerske hory Mts. of the Czech Republic: results based on ozone exposure and ozoneinduced visible symptoms. Environ Monit Assess 183:501-515

Inada N, Sakai A, Kuroiwa H, Kuroiwa T (1998) Three-dimensional analysis of the senescence program in rice (Oryza sativa L.) coleoptiles - investigations of tissues and cells by fluorescence microscopy. Planta 205:153-164

Innes JL, Skelly JM, Schaub M (2001) Ozone and broadleaves species. A guide to the identification of ozone-induced foliar injury. Birmensdorf, Eidgenössische Forschungsanstalt WSL. Haupt, Bern, Stuttgart, Wien, pp. 136

Jones A (2000) Does the plant mitochondrion integrate cellular stress and regulate programmed cell death? Trends Plant Sci 5:225-230

Kangasjärvi J, Jaspers P, Kollist H (2005) Signalling and cell death in ozone-exposed plants. Plant Cell Environ 28:1021-1036

Karnosky DF, Werner H, Holopainen T, Percy K, Oksanen T, Oksanen E, Heerdt C, Fabian P, Nagy J, Heilman W, Cox R, Nelson N, Matyssek R (2007) Free-air exposure systems to scale up ozone research to mature trees. Plant Biol 9:181-190

Kivimäenpää M, Selldén G, Sutinen S (2005) Ozone-induced changes in the chloroplast structure of conifer needles, and their use in ozone diagnostics. Environ Pollut 137:466-475

Klingberg J, Engardt M, Karlsson PE, Langner J, Pleijel H (2014) Declining ozone exposure of European vegetation under climate change and reduced precursor emissions. Biogeosciences 11: 5269-5283

Lauwaet D, Viaene P, Brisson E, van Lipzig NPM, van Noije T, Strunk A, Van Looy S, Veldemán N, Blyth L, De Ridder K, Janssen S (2014) The effect of climate change and emission scenarios on ozone 
concentrations over Belgium: a high-resolution model study for policy support. Atmos Chem Phys 14:5893-5904

Levine A, Pennell RI, Alvarez ME, Palmer R, Lamb C (1996) Calciummediated apoptosis in a plant hypersensitive disease resistance response. Curr Biol 6:427-437

Lichtenthaler HK (2013) Plastoglobuli, thylakoids, chloroplast structure and development of plastids. In: Biswal B, Krupinska K, Biswal UC (eds), Plastid development in leaves during growth and senescence. Book series: advances in photosynthesis and respiration 36: 337-361

Löw M, Herbinger K, Nunn AJ, Häberle KH, Leuchner M, Heerdt C, Werner H, Wipfler P, Pretzsch H, Tausz M, Matyssek R (2006) Extraordinary drought of 2003 overrules ozone impact on adult beech trees (Fagus sylvatica). Trees 20:539-548

Matyssek R, Bahnweg G, Ceulemans R, Fabian P, Grill D, Hanke DE, Kraigher H, Osswald W, Rennenberg H, Sandermann H, Tausz M, Wieser G (2007) Synopsis of the CASIROZ case study: Cabon sink strength of Fagus sylvatica L. in a changing environment - experimental risk assessment of mitigation by chronic ozone impact. Plant Biol 9:163-180

Matyssek R, Wieser G, Ceulemans R, Rennenberg H, Pretzsch K, Haberer K, Löw M, Nunn AJ, Werner H, Wipfler P, Oßwald W, Nikolova P, Hanke DE, Kraigher H, Tausz M, Bahnweg G, Kitao M, Dieler J, Sandermann H, Herbinger K, Grebenc T, Blumenröther M, Deckmyn G, Grams TEE, Heerdt C, Leuchner M, Fabian P, Häberle KH (2010) Enhanced ozone strongly reduces carbon sink strength of adult beech (Fagus sylvatica) - resume from the free-air fumigation study at Kranzberg Forest. Environ Pollut 158:25272532

Matyssek R, Wieser G, Calfapietra C, de Vries W, Dizengremel P, Ernst D, Jolivet Y, Mikkelsen TN, Mohren GMJ, Le Thiec D, Tuovinen JP, Weatherall A, Paoletti E (2012) Forests under climate change and air pollution: gaps in understanding and future directions for research. Environ Pollut 160:57-65

McQuattie CJ, Schier GA (1993) Effect of ozone and aluminium on a pitch pine (Pinus rigida) seedlings - needle ultrastructure. Can J For Res 23:1375-1387

Mikkelsen TN, Heide-Jørgensen HS (1996) Acceleration of leaf senescence in Fagus sylvatica L. by low levels of tropospheric ozone demonstrated by leaf colour, chlorophyll fluorescence and chloroplast ultrastructure. Trees 10:145-156

Miller PR, Stolte KW, Duriscoe DM, Pronos J (1996) Symptomology of ozone injury to pine foliage. In: Miller P, Stolte KW, Duriscoe D (eds) General Technical Report PSW-GTR-155-Web. http://www.fs. fed.us/psw/publications/documents/gtr-155/publisher.html. Assessed 31 October 2018

Mills G, Harmens H, Wagg S, Sharps K, Hayes F, Fowler D, Sutton M, Davies B (2016) Ozone impacts on vegetation in a nitrogen enriched and changing climate. Environ Pollut 208:898-908

Moura BB, de Souza SR, Alves ES (2011) Structural responses of Ipomoea nil (L.) Roth 'Scarlet O'Hara' (Convolvulaceae) exposed to ozone. Acta Bot Bras 25:122-129

Moura BB, Alves ES, de Souza SR, Domingos M, Vollenweider P (2014a) Ozone phytotoxic potential with regard to fragments of the Atlantic semi-deciduous forest downwind of Sao Paulo, Brazil. Environ Pollut 192:65-73

Moura BB, de Souza SR, Alves ES (2014b) Response of Brazilian native trees to acute ozone dose. Environ Sci Pollut Res 21:4220-4227

Moura BB, Alves ES, Marabesi MA, de Souza SR, Schaub M, Vollenweider P (2018) Ozone affects leaf physiology and causes injury to foliage of native tree species from the tropical Atlantic Forest of southern Brazil. Sci Total Environ 610:912-925

Novak K, Skelly JM, Schaub M, Kräuchi N, Hug C, Landolt W, Bleuler P (2003) Ozone air pollution and foliar injury development on native plants of Switzerland. Environ Pollut 125:41-52

Nunn AJ, Reiter IM, Häberle KH, Werner H, Langebartels C, Sandermann H, Heerdt C, Fabian P, Matyssek R (2002) "Free-air" ozone canopy fumigation in an old-growth mixed forest: concept and observations in beech. Phyton-Annales Rei Botanicae 42:105-119

Oksanen E, Sober J, Karnosky DF (2001) Impacts of elevated $\mathrm{CO}_{2}$ and/or $\mathrm{O}_{3}$ on leaf ultrastructure of aspen (Populus tremuloides) and birch (Betula papyrifera) in the Aspen FACE experiment. Environ Pollut 115:437-446

Paoletti E, Contran N, Bernasconi P, Günthardt-Goerg MS, Vollenweider P (2010) Structural and physiological responses to ozone in Manna ash (Fraxinus ornus L.) leaves of seedlings and mature trees under controlled and ambient conditions. Sci Total Environ (407: 16311643, 2009) 408: 2013-2024

Paoletti E, Materassi A, Fasano G, Hoshika Y, Carriero G, Silaghi D, Badea O (2017) A new-generation 3D ozone FACE (free air controlled exposure). Sci Total Environ 575:1407-1414

Pasqualini S, Piccioni C, Reale L, Ederli L, Della Torre G, Ferranti F (2003) Ozone-induced cell death in tobacco cultivar Bel W3 plants. The role of programmed cell death in lesion formation. Plant Physiol 133:1122-1134

Pell EJ, Schlagnhaufer CD, Arteca RN (1997) Ozone induced oxidative stress: mechanisms of action and reaction. Physiol Plant 100:264 273

Rao MV, Davis KR (2001) The physiology of ozone induced cell death. Planta 213:682-690

Reig-Armiñana J, Calatayud V, Cerveró J, García-Breijo FJ, Ibars A, Sanz MJ (2004) Effects of ozone on the foliar histology of the mastic plant (Pistacia lentiscus L.). Environ Pollut 132:321-331

Sá E, Martins H, Ferreira J, Marta-Almeida M, Rocha A, Carvalho A, Freitas S, Borrego C (2016) Climate change and pollutant emissions impacts on air quality in 2050 over Portugal. Atmos Environ 131: 209-224

Sanz MJ, Calatayud V (2011) Ozone injury in European forest species. http://wwwozoneinjuryorg Assessed 31 October 2018

Schaub M, Calatayud V, Ferretti M, (2010) Monitoring of ozone injury. Part VIII. Manual on methods and criteria for harmonized sampling, assessment, monitoring and analysis of the effects of air pollution on forests. UNECE, ICP Forests Programme Co-ordinating Centre, Hamburg (http://www.icp-forests.org/Manual.htm)

Schaub M, Bičárová S, Calatayud V, Ferretti M, Gottardini E, Häni M, Sicard P (2016) Ozone in forests - concentrations, effects, and fluxes in: Seidling, W. (ed)ICP Forests Executive Report 2016. Thünen Institute of Forest Ecosystems, Eberswalde, Germany, pp. 19, eISSN 2198-6541

Sharma S, Chatani S, Mahtta R, Goel A, Kumar A (2016) Sensitivity analysis of ground level ozone in India using WRF-CMAQ models. Atmos Environ 131:29-40

Simon H, Reff A, Wells B, Xing J, Frank N (2015) Ozone trends across the United States over a period of decreasing NOx and VOC emissions. Environ Sci Technol 49:186-195

Soda C, Bussotti F, Grossoni P, Barnes J, Mori B, Tani C (2000) Impacts of urban levels of ozone on Pinus halepensis foliage. Environ Exp Bot 44:69-82

Tevini M, Steinmüller D (1985) Composition and function of plastoglobuli. 2. Lipid-composition of leaves and plastoglobuli during senescence. Planta 163:91-96

Trenberth KE, Dai A, van der Schrier G, Jones PD, Barichivich J, Briffa KR, Sheffield J (2014) Global warming and changes in drought. Nat Clim Chang 4:17-22

Vainonen JP, Kangasjärvi J (2015) Plant signalling in acute ozone exposure. Plant Cell Environ 38:240-252

Vollenweider P, Günthardt-Goerg MS (2006) Diagnosis of abiotic and biotic stress factors using the visible symptoms in the foliage. Environ Pollut (137:455-465, 2005 140:562-571

Vollenweider P, Ottiger M, Günthardt-Goerg MS (2003) Validation of leaf ozone symptoms in natural vegetation using microscopical methods. Environ Pollut 124:101-118 
Vollenweider P, Fenn ME, Menard T, Günthardt-Goerg M, Bytnerowicz A (2013) Structural injury underlying mottling in Ponderosa pine needles exposed to ambient ozone concentrations in the San Bernardino Mountains near Los Angeles, California. Trees 27:895-911

Watson L, Lacressonnière G, Gauss M, Engardt M, Andersson C, Josse B, Marécal V, Nyiri A, Sobolowski S, Siour S, Szopa S, Vautard R (2016) Impact of emissions and $+2{ }^{\circ} \mathrm{C}$ climate change upon future ozone and nitrogen dioxide over Europe. Atmos Environ 142:271-285

Werner H, Fabian P (2002) Free-air fumigation of mature trees - a novel system for controlled ozone enrichment in grown-up beech and spruce canopies. Environ Sci Pollut Res 9:117-121

Yamasaki H, Sakihama Y, lkehara N (1997) Flavonoid-peroxidase reaction as a detoxification mechanism of plant cells against $\mathrm{H}_{2} \mathrm{O}_{2}$. Plant Physiol 115: 1405-1412
Contribution of the co-authors: P. Vollenweider and M.S. GünthardtGoerg conceived this study, analyzed and interpreted the pictures and wrote the paper. T. Menard carried out the microscopic work. M. Baumgarten supplied the ozone values. M. Schaub reviewed and commented the paper. R. Matyssek conceived and supervised the CASIROZ face experiment and reviewed the paper.

Publisher's note Springer Nature remains neutral with regard to jurisdictional claims in published maps and institutional affiliations. 